Distribution Category

UC-66a

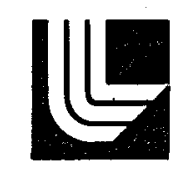

LAWRENCE LIVERMORE LABORATORY

University of Cahfornia/Livermore, California/94550

UCRL-52354

\title{
SUBSURFACE STRUCTURE OF THE SOUTHERN PORTION OF THE SALTON SEA GEOTHERMAL FIELD
}

Marjorie A. Chan

John D. Tewhey

MS date: October 1977

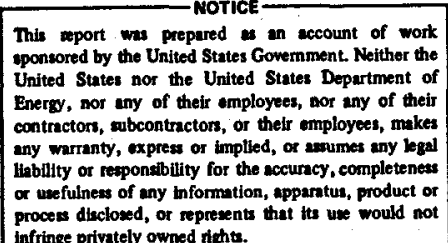

infringe privately owned rights. 


\section{DISCLAIMER}

This report was prepared as an account of work sponsored by an agency of the United States Government. Neither the United States Government nor any agency Thereof, nor any of their employees, makes any warranty, express or implied, or assumes any legal liability or responsibility for the accuracy, completeness, or usefulness of any information, apparatus, product, or process disclosed, or represents that its use would not infringe privately owned rights. Reference herein to any specific commercial product, process, or service by trade name, trademark, manufacturer, or otherwise does not necessarily constitute or imply its endorsement, recommendation, or favoring by the United States Government or any agency thereof. The views and opinions of authors expressed herein do not necessarily state or reflect those of the United States Government or any agency thereof. 


\section{DISCLAIMER}

Portions of this document may be illegible in electronic image products. Images are produced from the best available original document. 


\section{CONTENTS}

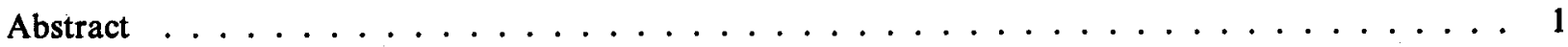

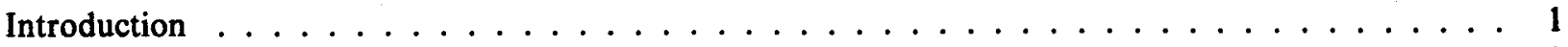

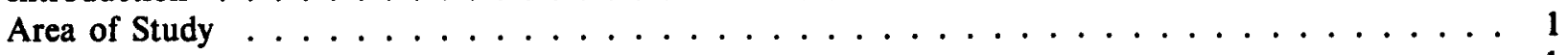

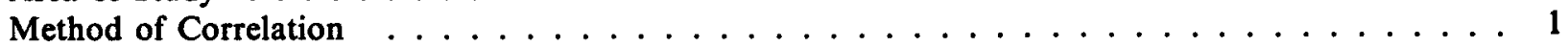

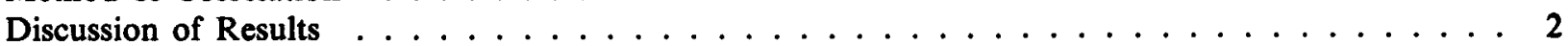

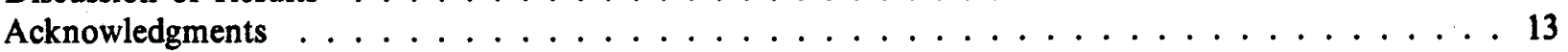

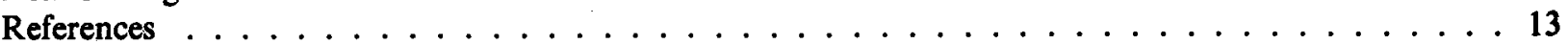

\section{ILLUSTRATIONS}

1. Location of Salton Sea Geothermal Field and nearby faults in Imperial Valley

2. Well locations in Salton Sea Geothermal Field

3. Example of spontaneous potential (SP) $\log$ in sand-shale sequence

4. SP logs of $350-\mathrm{ft}(100-\mathrm{m})$ "marker" interval from nine geothermal wells

5. Five-well correlation diagram extending north to south from Elmore 1 to Sinclair 3

6. Three-well correlation diagram extending north to south from Elmore 3 to Sinclair 4 through Magmamax 1

7. Three-well correlation diagram extending north to south from Elmore 3 to Sinclair 4 through Magmamax 3

8. Three-well correlation diagram extending north to south from Elmore 3 to Sinclair 4 through Magmamax 2

9. Five-well correlation diagram extending west to east from Magmamax 2 to Woolsey 1

10. Three-well correlation diagram extending west to east from Sinclair 4 to Sinclair 3

11. Structural contour diagram representing depth to top of thick shale unit in "marker" interval 


\title{
SUBSURFACE STRUCTURE OF THE SOUTHERN PORTION OF THE SALTON SEA GEOTHERMAL FIELD
}

\begin{abstract}
Subsurface correlation of sedimentary strata has been attempted among ten geothermal wells in the southern portion of the Salton Sea Geothermal Field. The spontaneous potential (SP) log has been the principal tool used for correlation purposes. The structure that emerges from the correlation diagrams is a shallow plunging syncline with an east-west axis perpendicular to the axis of the Salton Trough.
\end{abstract}

\section{INTRODUCTION}

The southern portion of the Salton Sea Geothermal Field (SSGF) is currently being tested and evaluated for its geothermal potential by Lawrence Livermore Laboratory and a number of other organizations. A knowledge of the subsurface structure in the field is necessary for reservoir engineering and hydrology studies. The general patterns of geologic structure and stratigraphic correlation have been outlined in previous studies. ${ }^{1-3}$ In the present study, we provide a more detailed picture of the subsurface geology.

\section{AREA OF STUDY}

Subsurface correlation of sedimentary strata has been attempted among ten geothermal wells in the southern portion of the SSGF (Fig. 1). The distribution of wells in the study area permitted the construction of a network of six cross sections, four oriented in a north-south direction and two in an east-west direction (Fig. 2). The cross sections range in length from less than a mile $(1 \mathrm{~km})$ to more than 2 $\mathrm{mi}(3.5 \mathrm{~km})$, and the area covered by the net is approximately $8 \mathrm{sq} \mathrm{mi}(20 \mathrm{sq} \mathrm{km})$. The LLL geothermal test facility is located in the center of the net adjacent to the Magmamax 1 well.

\section{METHOD OF CORRELATION}

The spontaneous potential (SP) log has been the principal tool used for correlation purposes in this report. The SP curve is a recording vs depth of the difference between the potential of a movable electrode in the borehole and the fixed potential of a surface electrode (Fig. 3). The SP $\log$ is useful to detect permeable sandstones, to determine qualitative indications of bed shaliness, and to locate boundaries between sand and shale units, thereby permitting correlation of such beds from well to well. SP logs are not unique for the purposes of correlation; other geophysical logs work equally well. Resistivity and density logs from several wells in the SSGF corroborate the SP correlations but are 
not shown in the correlation diagrams appearing later in this report in order to keep the diagrams as simple as possible.

"Marker" intervals characterized by distinctive patterns on geophysical logs are very helpful in correlating strata over the long distances between wells. Such an interval is present in all of the wells in the study area. The marker interval varies in thickness from approximately $300 \mathrm{ft}(90 \mathrm{~m})$ to $400 \mathrm{ft}$
$(120 \mathrm{~m})$ and consists of an $80-\mathrm{ft}(25-\mathrm{m})$ thick shale unit overlain by a sequence of uniformly interbedded sandstones and shales. The depth to the top of the sequence varies from $1700 \mathrm{ft}(520 \mathrm{~m})$ in Elmore 3 to $2300 \mathrm{ft}(700 \mathrm{~m})$ in Magmamax 2. In Fig. 4 the marker intervals from nine wells are shown in juxtaposition in order to emphasize their similarities. Thick $(\geqslant 100 \mathrm{ft})$ sand and shale units are other horizons that are correlated in Figs. 5 through 10.

\section{DISCUSSION OF RESULTS}

On the basis of drill cuttings, core samples, and geophysical logs from geothermal wells, the sequence of sedimentary rocks in the SSGF have been divided into three categories: cap rock, reservoir rock, and hydrothermally altered reservoir rock. ${ }^{3}$ The boundaries between intervals of the three rock types are indicated for the Magmamax and Woolsey wells in Figs. 5 through 10. The most easily correlatable sequence of strata in the SSGF is the $2000-\mathrm{ft}(600-\mathrm{m})$ thickness of reservoir rock that occurs beneath the cap rock and above the sequence of hydrothermally altered reservoir rock. The evaporite and carbonate-rich cap rock sequence produces a flat, featureless SP curve that is of little

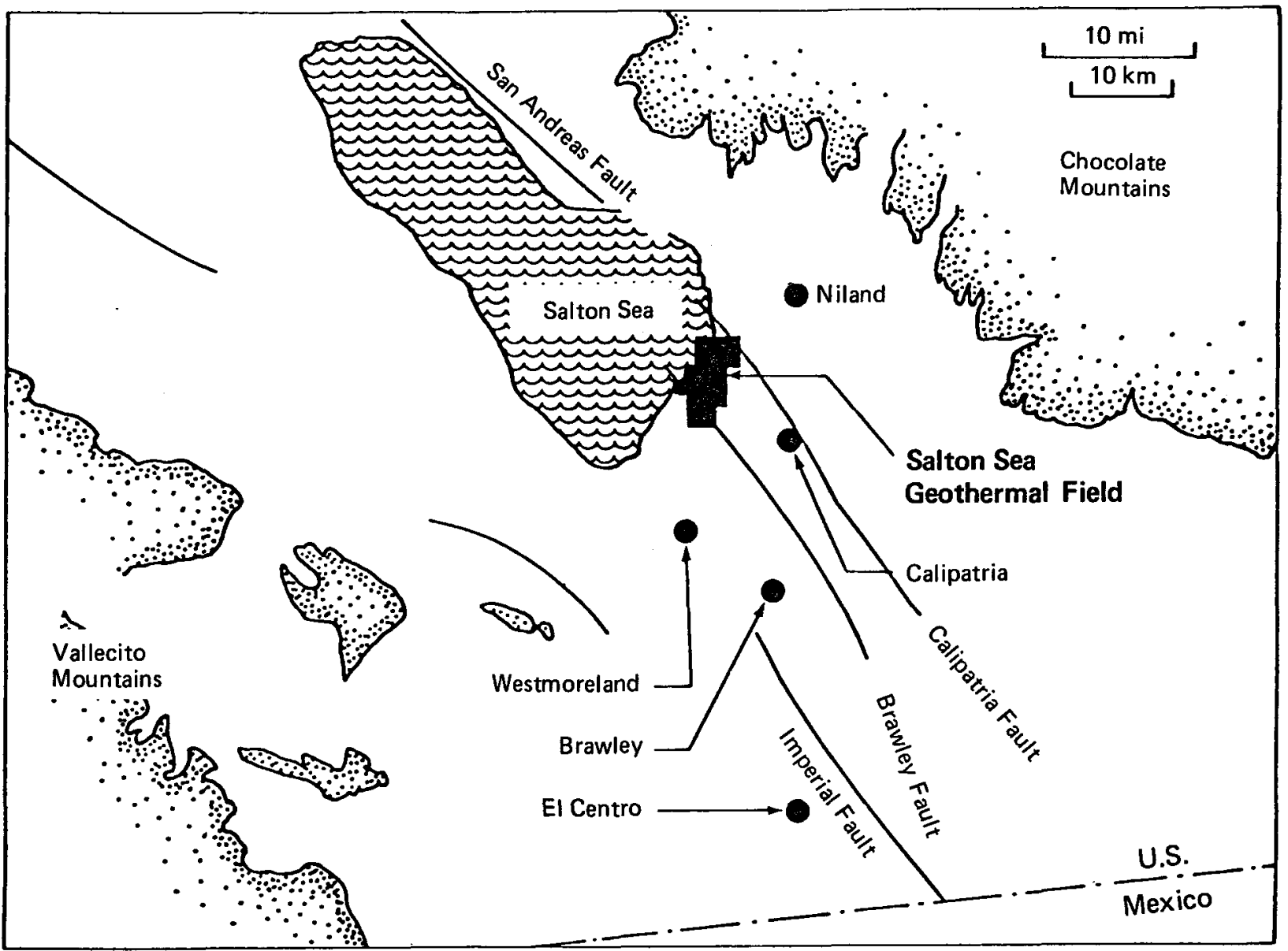

Fig. 1. Location of Salton Sea Geothermal Field and nearby faults in Imperial Valley, California (basement rocks indicated by stippled pattern). 


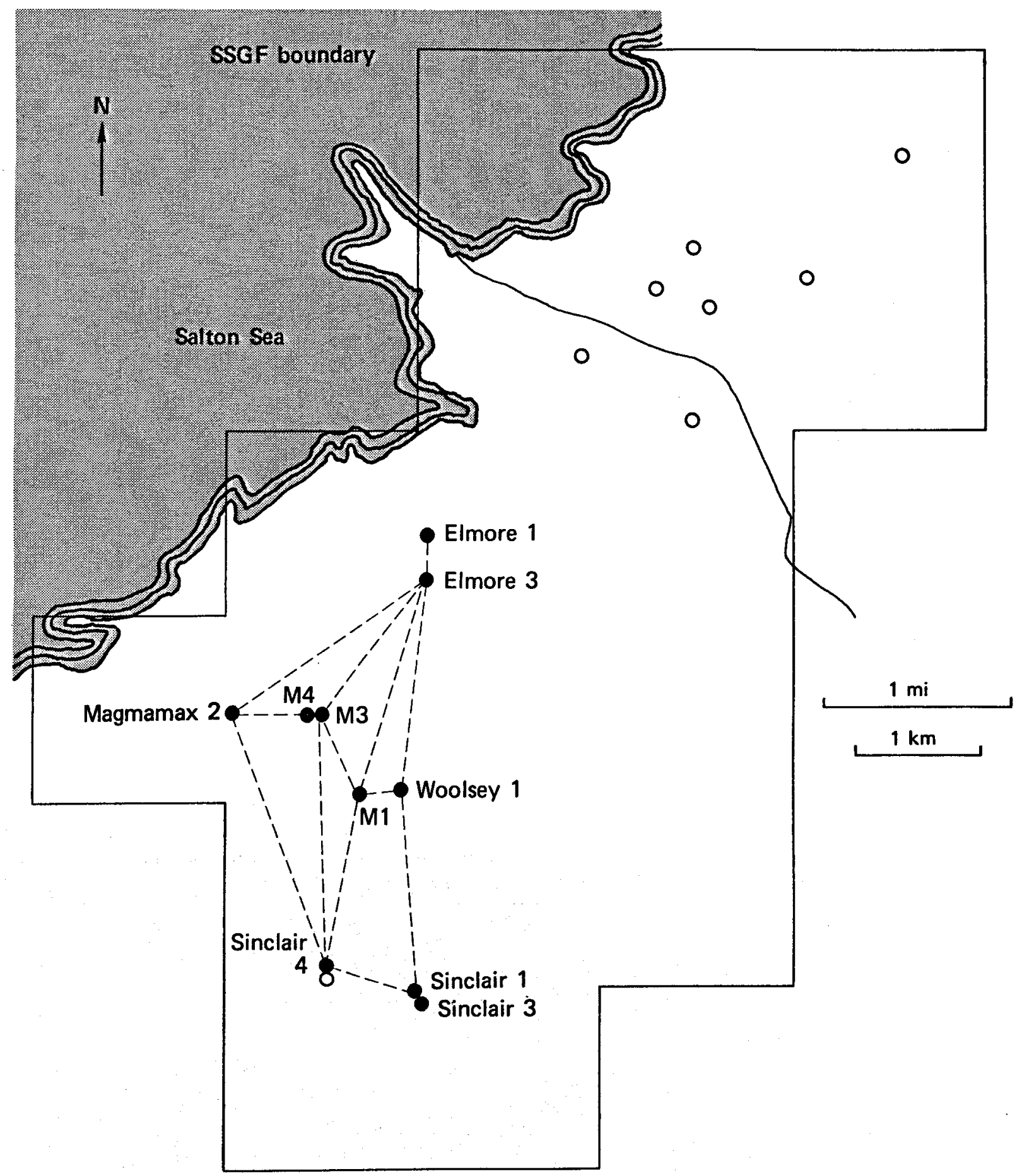

Fig. 2. Well locations in Salton Sea Geothermal Field (closed circles indicate the ten wells included in study; open circles indicate wells not included in study). 


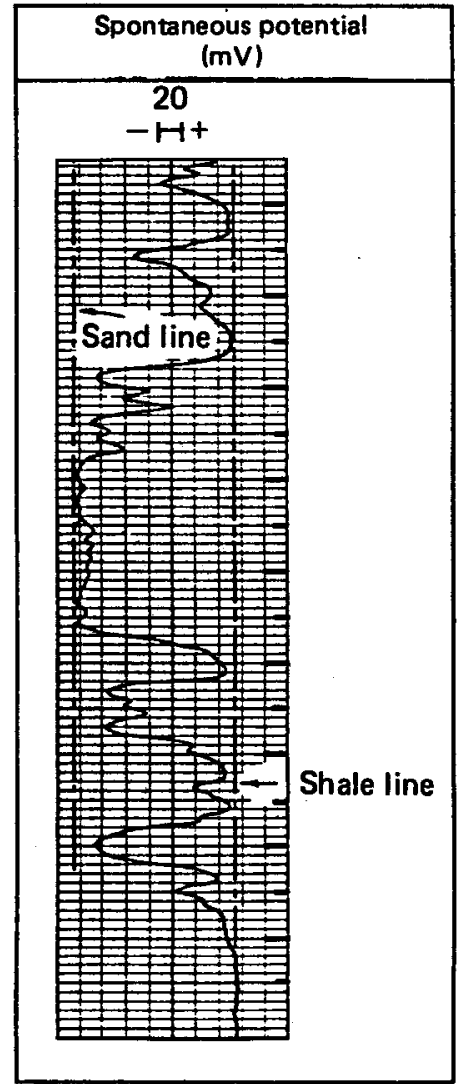

Fig. 3. Example of spontaneous potential (SP) $\log$ in sand-shale sequence.

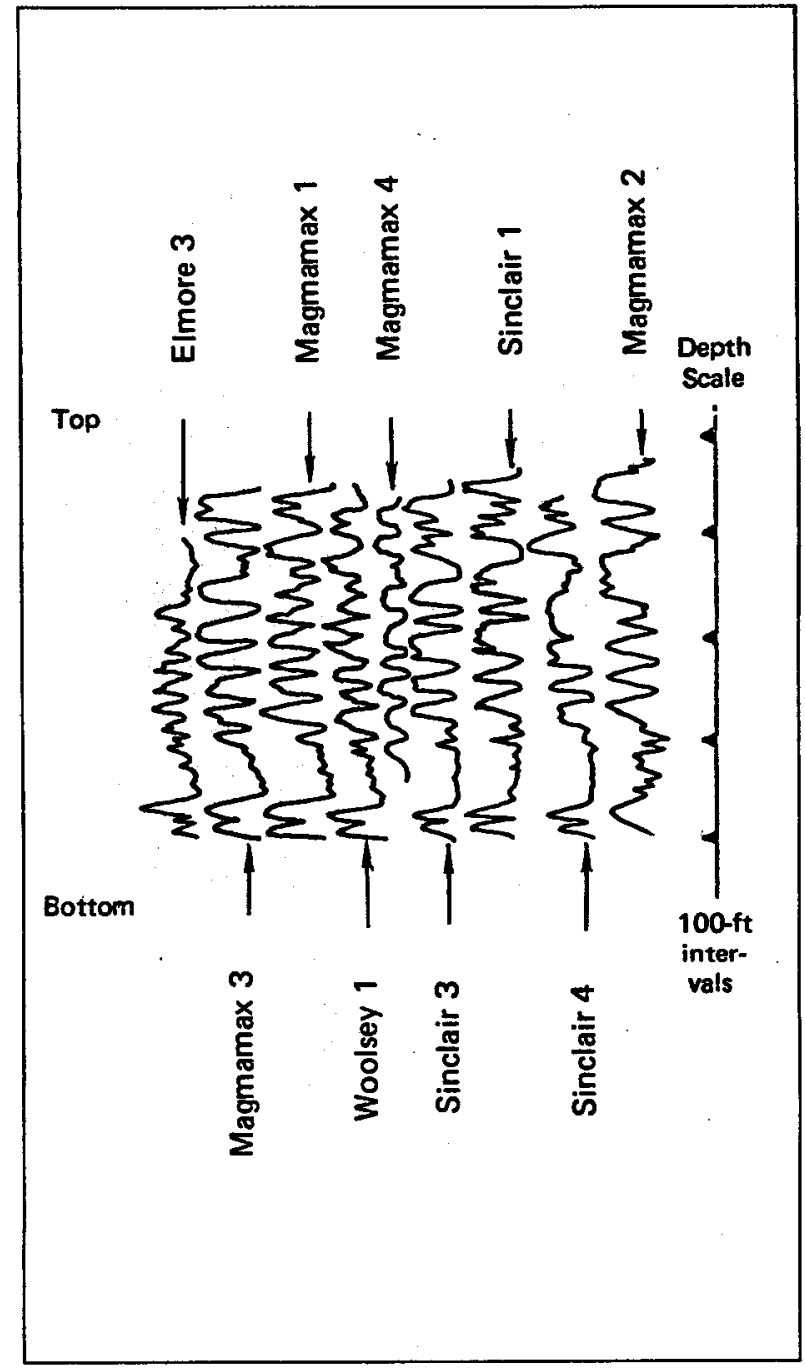

Fig. 4. SP logs of 350-ft (100-m) "marker" interval from nine geothermal wells (intervals are placed in juxtaposition to emphasize similarities that are not readily apparent on correlation diagrams). 


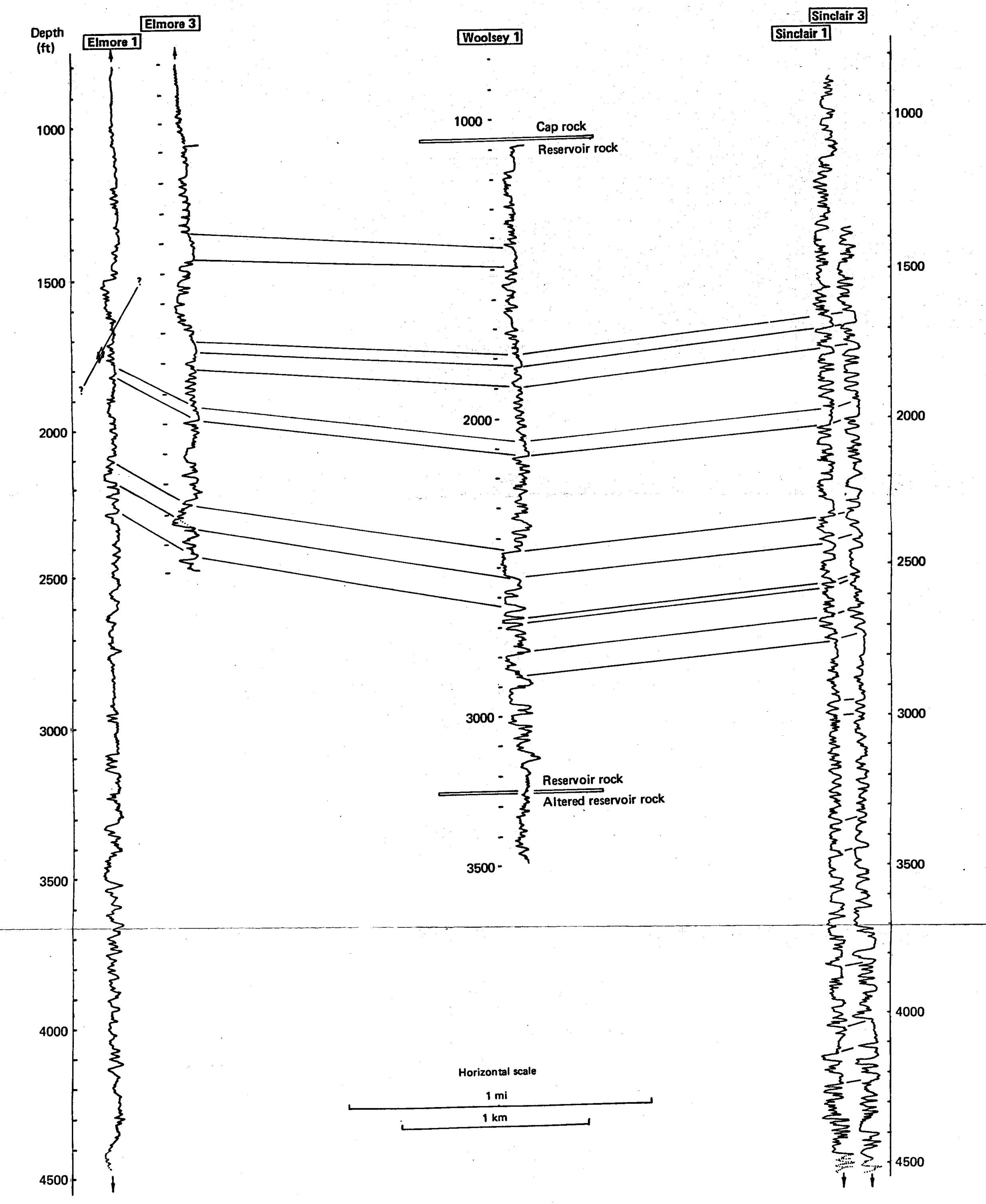

Fig. 5. Five-well correlation diagram extending north to south from Elmore 1 to Sinclair 3. 


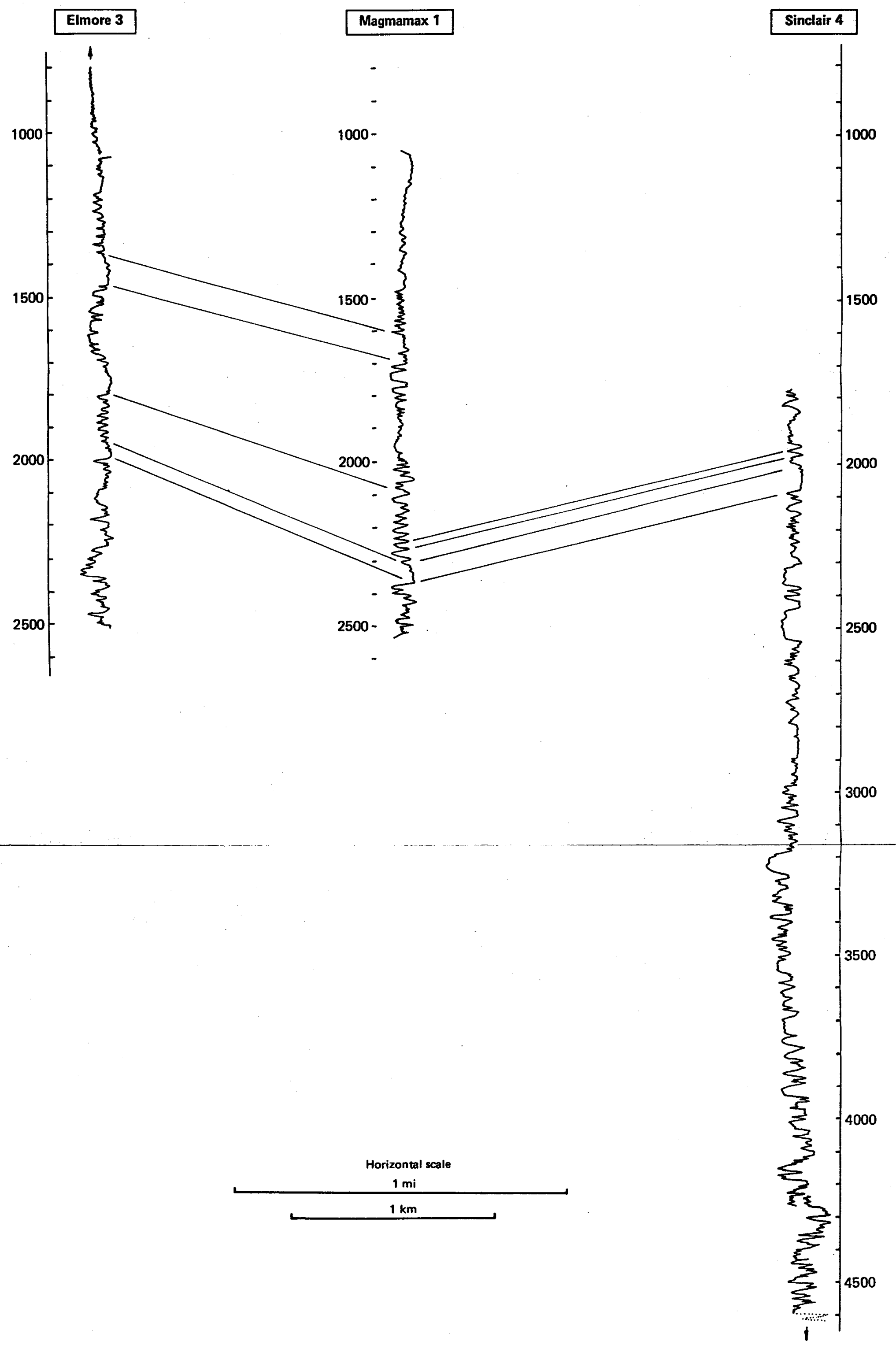

Fig. 6. Three-well correlation diagram extending north to south from Elmore 3 to Sinclair 4 through Magmamax 1. 


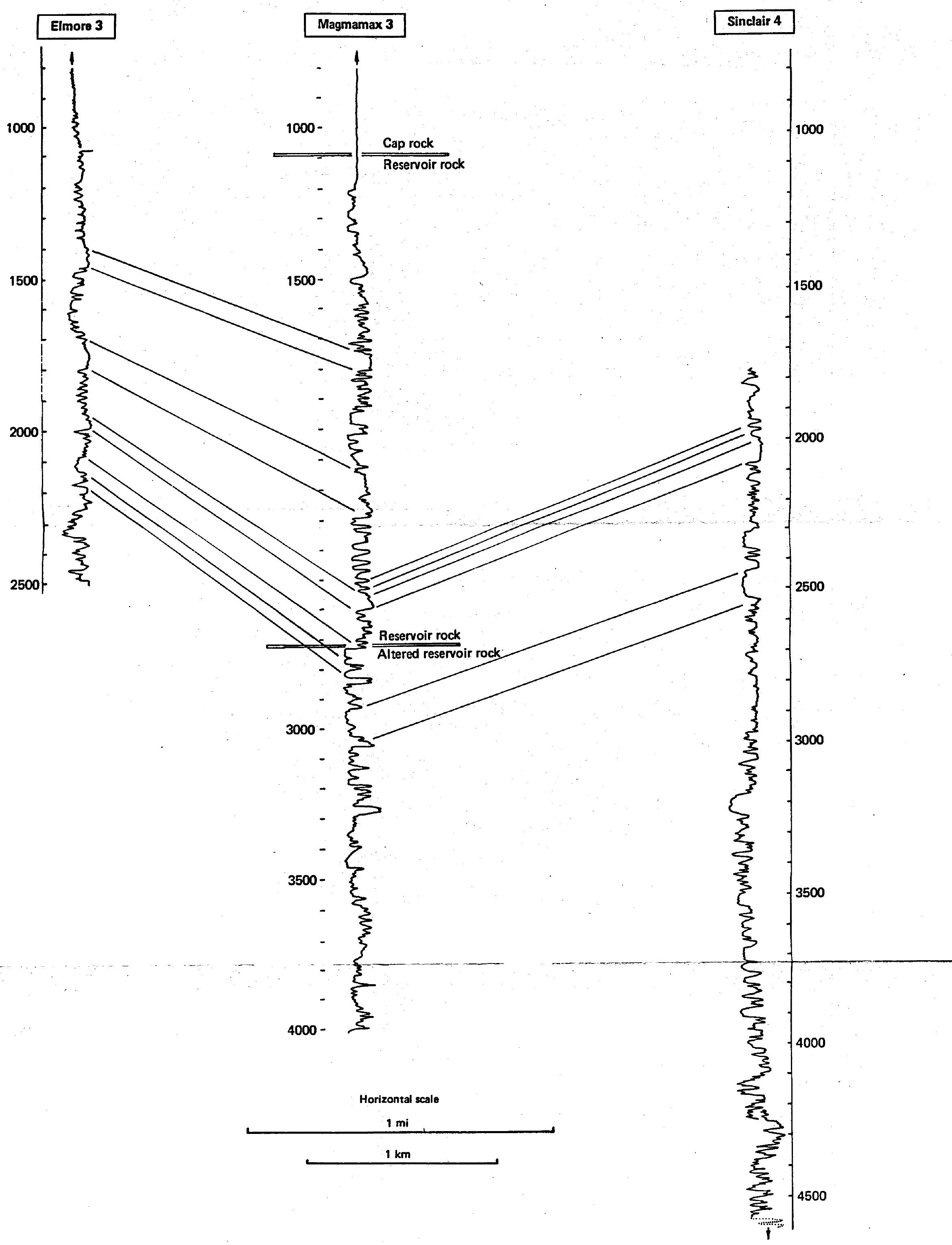

Fig. 7. Three-well correlation diagram extending north to south from 


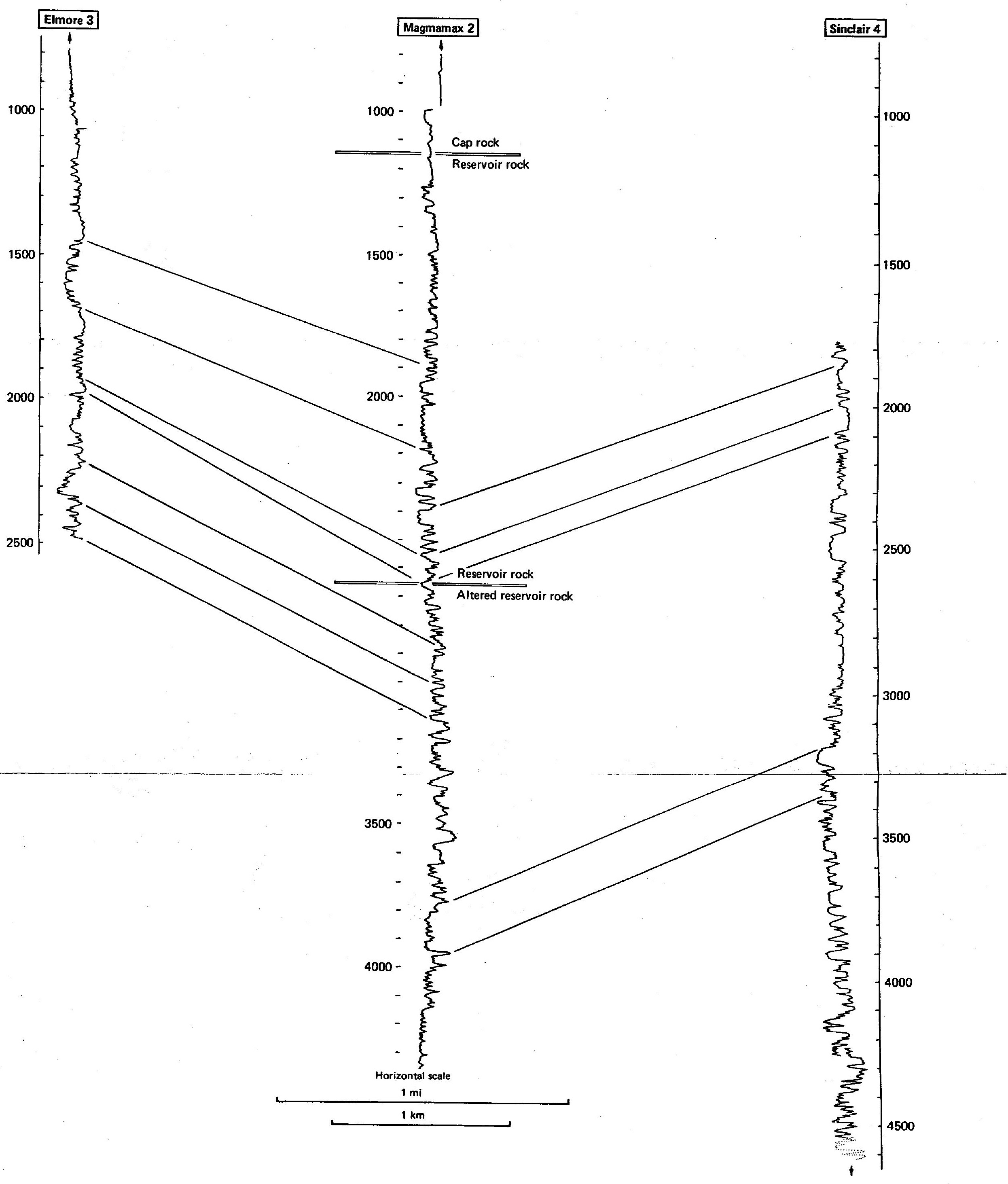




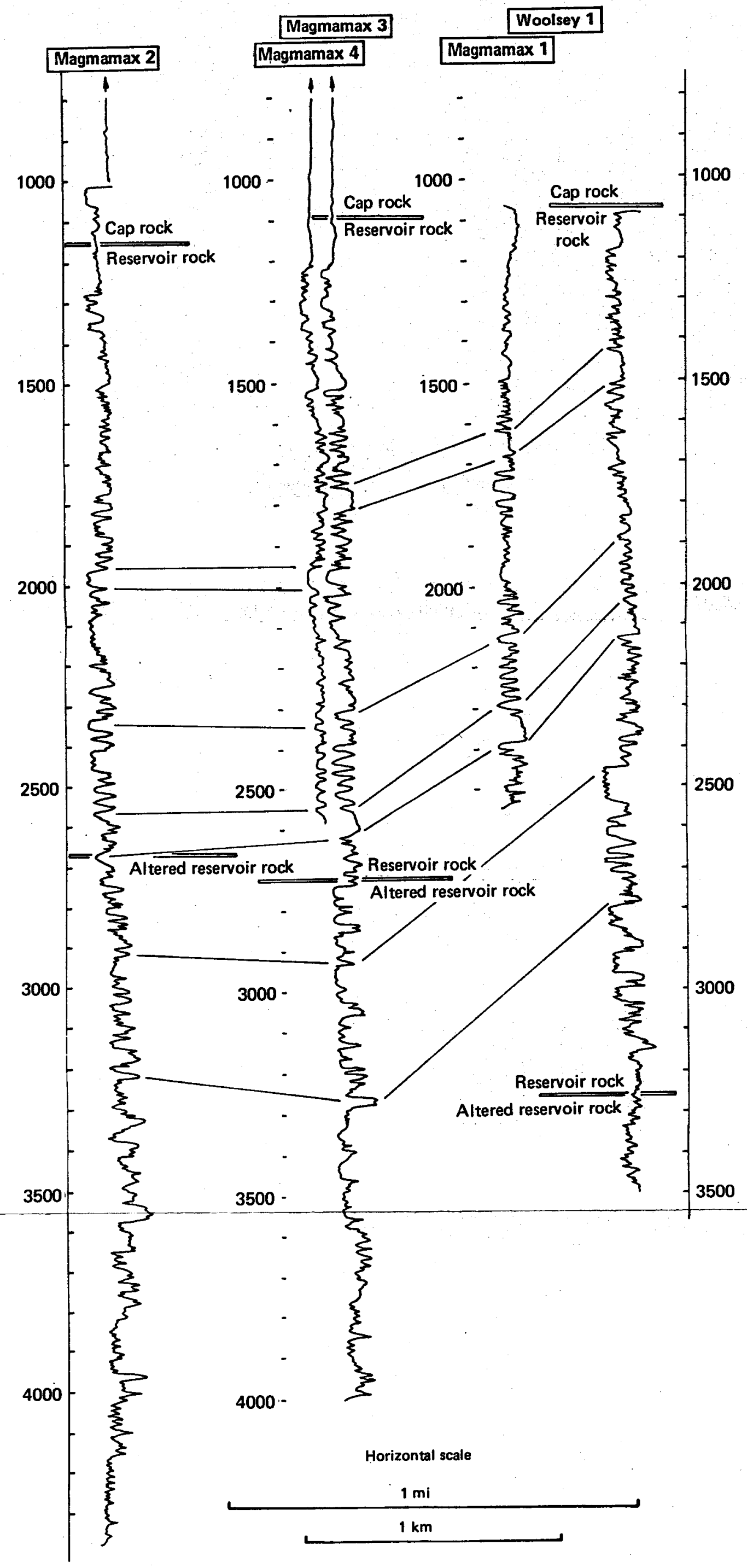

Fig. 9. Five-well correlation diagram extending west to east from Magmamax 2 to Woolsey 1. 


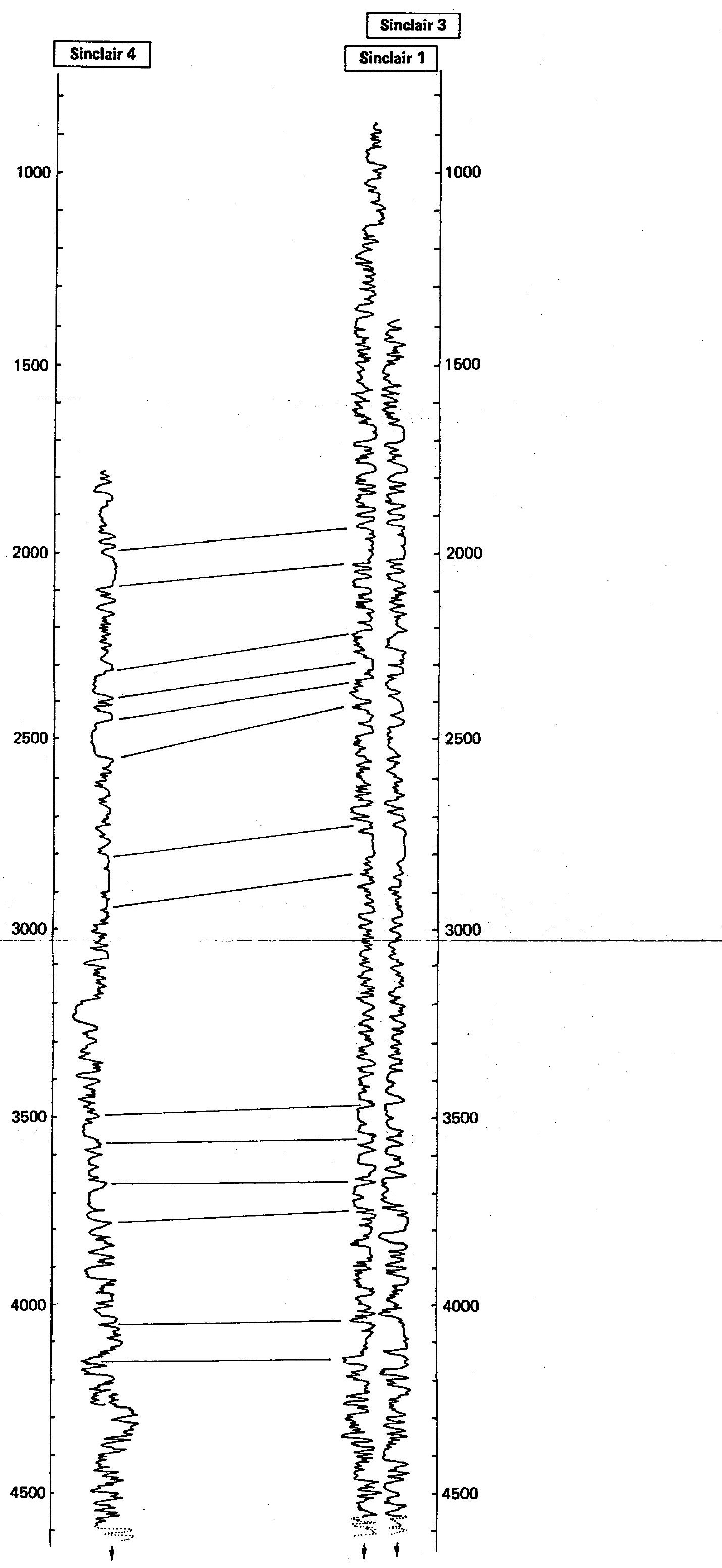

Fig. 10. Three-well correlation diagram extending west to east from Sinclair 4 to Sinclair 3. 


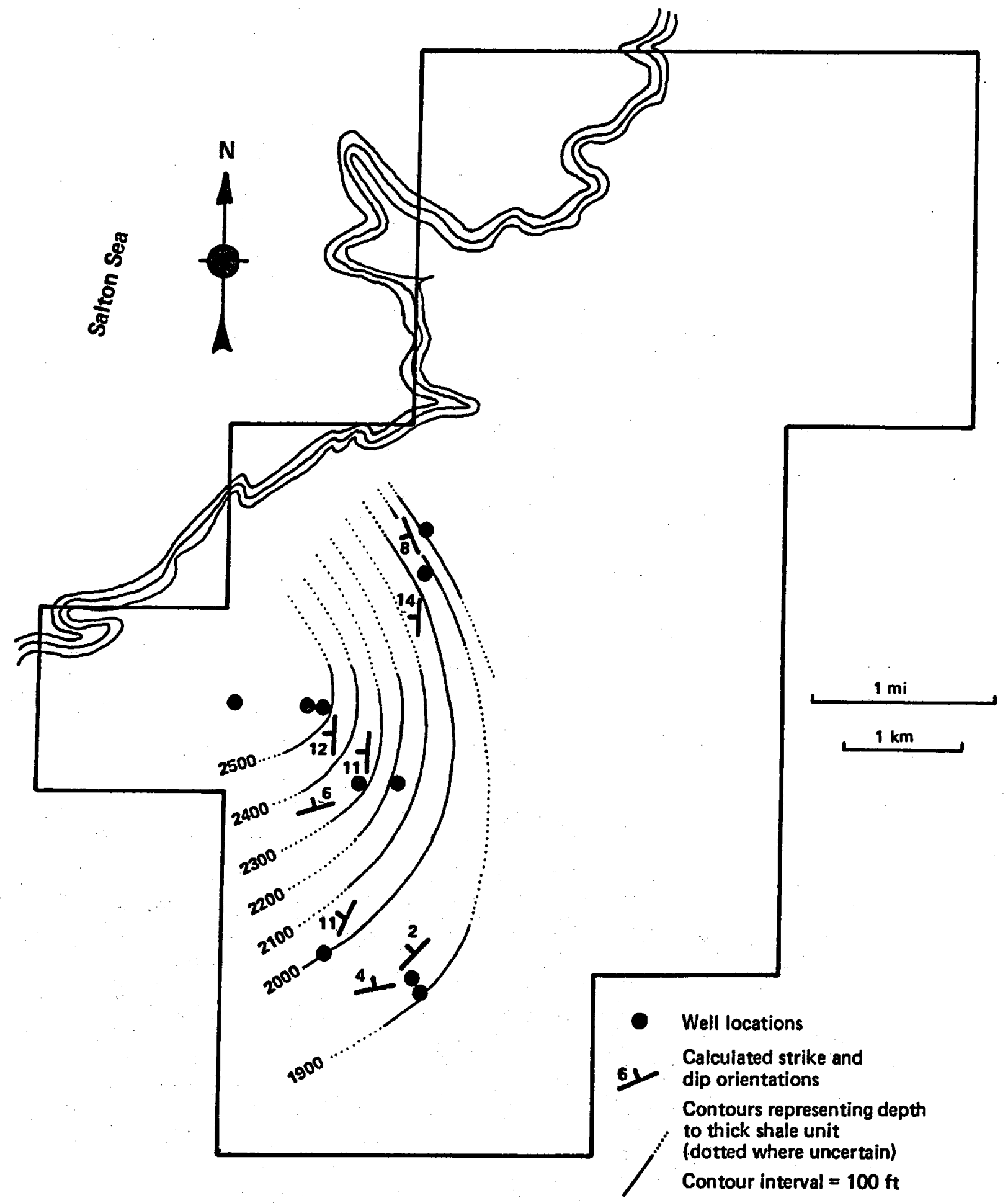

Fig. 11. Structural contour diagram representing depth to top of thick shale unit in "marker" interval (structure is westward plunging syneline). 
use for purposes of detailed correlation. For this reason, most of the $1100-\mathrm{ft}(300-\mathrm{m})$ cap rock sequence is not shown in Figs. 5 through 10. The potential for correlation is also somewhat reduced in the zone of altered reservoir rock. The process of hydrothermal alteration promotes the growth of new minerals in the pore space of permeable sandstones and in shale partings and fractures. The alteration process narrows the range of response of diverse rock types to the SP log which, in turn, makes correlation more difficult. Very few correlations of altered reservoir rocks have been made in Figs. 5 through 10.

The structural picture that emerges from the six cross sections is one of a broad syncline whose eastwest axis is perpendicular to the axis of the Salton Trough. The syncline has a shallow westward plunge toward the center of the trough. In Fig. 11, the syncline has been delineated by means of a structural contour map of the top of the thick shale unit that is present near the bottom of the marker interval (see Fig. 4). Depths to the shale unit were obtained from geophysical logs and therefore represent distances below the drilling platform (Kelly Bushing), which is $12 \mathrm{ft}$ above the ground surface. Strike-dip symbols were arrived at by (1) determining apparent dips of the shale unit between adjacent wells, and (2) plotting apparent dips on a steronet in order to determine the true strike and dip. Structure contours were drawn on the basis of known depths to the shale unit in the various wells and the orientation of the calculated strike-dip symbols.

Another feature ascertained from the correlation diagrams is a general tendency for southwest-tonortheast thinning of sedimentary units. This characteristic can be recognized in the marker intervals (Fig. 4). 


\section{ACKNOWLEDGMENTS}

We are grateful to the following people of Lawrence Livermore Laboratory who lent support and assistance in this study: Paul Kasameyer for his review and suggestions on the manuscript, and Larry Owen for his helpful comments and suggestions.

\section{REFERENCES}

1. D. Towse and T. D. Palmer, Summary of Geology at the ERDA-Magma-SDG\&E Geothermal Test Site, Lawrence Livermore Laboratory, Rept UCID-17008 (1976).

2. W. Randall, An Analysis of the Subsurface Structure and Stratigraphy of the Salton Sea Geothermal Anomaly, Imperial Valley, California, Ph.D. Thesis, University of California, Riverside, CA. (1974).

3. J. D. Tewhey, Geologic Characteristics of a Portion of the Salton Sea Geothermal Field, Lawrence Livermore Laboratory, Rept UCRL-52267 (1977). 